\author{
이소성 갑상선에서 기인한 결절성 과증식증 1 예 \\ 대구파티마병원 이비인후과 \\ 심형준·문석진 · 박수찬 · 여창기
}

\title{
A Case of Nodular Hyperplasia Arising from Ectopic Thyroid
}

Hyung Jun Shim, MD, Seok Jin Moon, MD, Soo Chan Park, MD and Chang Ki Yeo, MD

Department of Otolaryngology-Head and Neck Surgery, Daegu Fatima Hospital, Daegu, Korea

\begin{abstract}
-ABSTRACT -
Ectopic thyroid is an uncommon embryological aberration characterized by the presence of thyroid tissue in a site other than its usual pretracheal region. Nodular hyperplasia arising from ectopic thyroid is extremely rare. The authors report a recent case of nodular hyperplasia arising from ectopic thyroid in the anterior neck of a 27year-old man. Thyroid scan should be employed when making a diagnosis and therapeutic plan of this disease. (J Clinical Otolaryngol 2005;16:281-283)
\end{abstract}

KEY WORDS : Ectopic thyroid - Nodular hyperplasia.

\section{서론}

이소성 갑상선은 1869년 Hickman에 의해 처음으로 보 고된 이후 현재까지 약 300 예 정도의 보고가 있었으며 ${ }^{1)}$ 기관 앞의 정상 갑상선 이외에 존재하는 것으로 설맹공 부 위에서 가장 많이 발생하며, 발생부위에 따라서 크게 설하 부, 설골부, 설골상부, 설골하부로 구분되며, 드물게 종격 동 심낭기관이나 식도에서도 발생하기도 한다. ${ }^{2) 3}$ 이러한 이소성 갑상선에서 기인한 결절성 과증식증은 매우 희귀한 질환으로 이에 저자는 문헌 고찰과 함께 보고하는 바이다.

\section{증 례}

27세 남자 환자로 6개월 전부터 시작된 전경부의 종

논문접수일 : 2005년 9월 3일

심사완료일 : 2005년 10월 3일

교신저자 : 여창기, 701- 600 대구광역시 동구 신암4동

576- 31 대구파티마병원 이비인후과

전화 : (053) 940- 7350. 전송 : (053) 957- 7417

E- mail : ckyeo@ fatima.or.kr
물을 주소로 2003년 5월 본원 이비인후과에 내원하였으 며 당시 연하장애, 애성, 촉진시 통증 등의 증상은 없었 다. 과거력 및 가족력상 특이 사항이 없었고 신체검사상 내원시 활력증후는 정상이었다. 갑상연골 하부에 지름 1.5 $\mathrm{cm}$ 크기의 원형모양의 주위와 경계가 명확하고 무통성 의 종물이 만져졌고 갑상선은 정상적인 위치에서 촉지되 었다. 갑상선 기능 이상을 보이는 이학적 소견은 존재하 지 않았고 경부 전산화 단층촬영상 경부 정중부에 타원 형의 종괴가 윤상연골과 상부기관에 걸쳐 정상 갑상선과 동일 음영으로 관찰되었으며(Fig. 1) 주위 경부 임파선의 종대는 없었다. $99 \mathrm{mT}$ c- pertechnetate 갑상선 주사상 정상적인 갑상선은 요오드 섭취를 보인 반면 종물은 섭 취가 되지 않았다 Fig. 2). 일반 혈액검사와 일반 생화학 검사는 모두 정상범위였으며 갑상선 기능 검사는 T 3163 $\mathrm{ng} / \mathrm{dl}, \mathrm{T} 44.8 \mu \mathrm{g} / \mathrm{dl}$, 갑상선 자극 호르몬(T SH) $0.9 \mu \mathrm{IU} /$ $\mathrm{ml}$ 로 정상범위였다.

절제생검을 시행하였고 생검결과 이소성 갑상선 조직에 서 기인한 결절성 과증식증(Fig. 3) 으로 진단되어 현재까 지 재발 없이 외래 추적 관찰 중이다. 


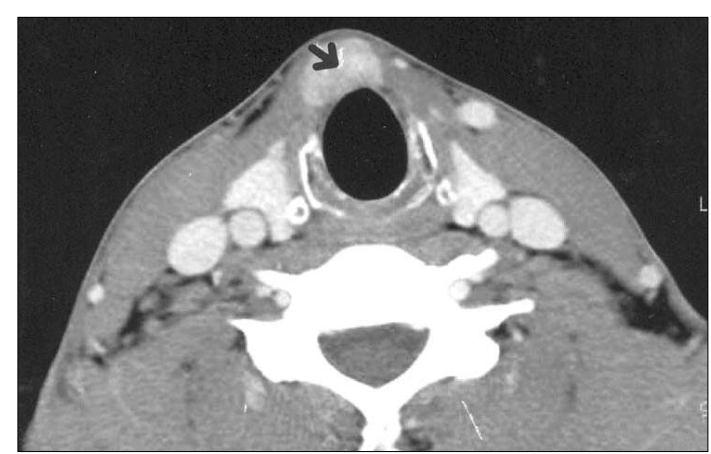

Fig. 1. Preoperative axial CT scan. The arrow indicate a mass lesion on anterior tracheal area.

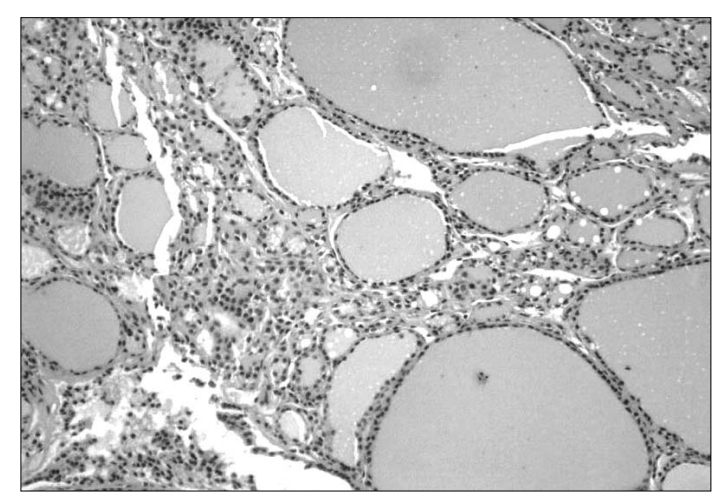

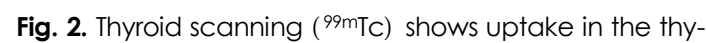
roid gland. but there is no uptake in mass.

\section{고 찰}

이소성 갑상선은 인구 $100,000 ~ 300,000$ 명 중 1명의 발병률을 보이고 갑상선 질환을 가지고 있는 환자 4000 8000 명당 1 명에서 발병하며 여자에서 남자보다 4 배정 도 많이 발생한다.) 대개는 청소년기나 임신 후에 커지는 데 호르몬의 생리적인 요구가 많기 때문이다. 주요 증상 으로는 경부 종물이나 연하곤란, 호흡곤란, 발성곤란 등 이 나타날 수 있으난) 본 증례의 증상은 경부종물외 특 이 소견은 없었다.

이소성 갑상선은 갑상선이 태생기에 갑상설관을 형성 하며 경부로 하강하기때문에 갑상설관의 개구부인 맹공에 서 경부의 정상적인 갑상선 위치사이 어디서나 발견될 수 있으며 그 중 설기저부가 가장 호발하는 장소로 $90 \%$ 정 도를 차지하며 그 다음이 전경부의 갑상설관 위치이므로

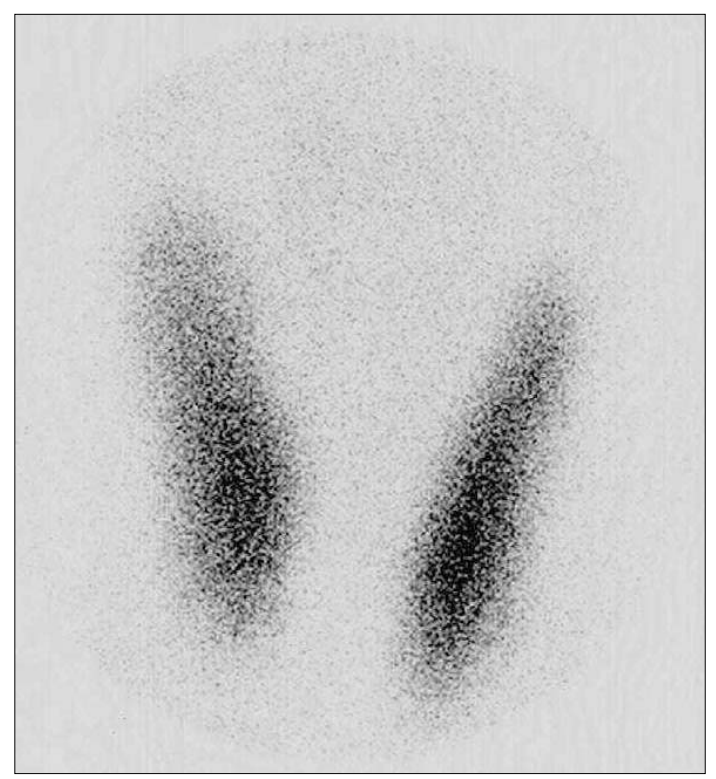

Fig. 3. Microscopic finding of the mass (nodular hyperplasia : variable sized dilated follicles containing colloid material, oval shaped follicle cell with fine chromatin, $\mathrm{H}$ \& E stain $\times 100$ ).

반드시 갑상설관과 감별되어야 한다. ${ }^{46)}$ 종종 이소성 갑 상선만이 유일하게 갑상선 기능을 대신하기도 한다. 경부 정중부의 종물을 주소로 내원한 환자에 있어서 임상적 으로 갑상설관 낭종으로 생각하고 절제하였다가 영구적인 갑상선 기능 저하증을 초래한 경우도 있으므로 반드시 갑 상선 주사를 술 전에 시행하여 기능성 여부를 파악할 필 요가 있으며 ${ }^{7}$ 본 증례에서는 정상적인 갑상선이 기능을 하였고 이소성 갑상선은 요오드 섭취가 되지 않았다.

이소성 갑상선에서 유두상 갑상선 암종이나 비분화성 암종이 생긴 증례가 있으며 ${ }^{80}$ 어머니와 아들에서 생긴 이소성 갑상선의 유전성에 대한 보고도 있다.11)

진단은 전산화 단층촬영술상 갑상선 조직은 풍부한 혈 액분포로 밀도가 증가된 음영으로 관찰되며, 경부 초음파 는 낭종성 병변의 구분이 용이하며 ${ }^{12)}$ 갑상선 주사법은 이 소성 갑상선의 기능성이나 정상 위치의 갑상선의 기능을 평가 할 수 있다.

감별해야 할 질환으로는 갑상설관 낭종, 유피낭종, 지 방종, 임파선등이 있다. ${ }^{13)}$

증상이 없고 정상적인 호르몬 수치를 가진 환자는 치 료가 필요 없으나 증상이 있는 환자는 이소성 갑상선의 
크기, 위치, 환자의 연령 및 갑상선 기능 상태 등을 고려 하여 치료 계획을 세워야 한다.

이소성 갑상선의 주 치료는 약물요법이며 약물에 의한 치료는 갑상선 호르몬을 투여하여 갑상선 자극 호르몬 분 비를 억제하여 이소성 갑상선의 크기를 줄이는 게 목적 이나 호르몬 치료에도 진행하는 갑상선 기능저하나 연하 곤란, 출혈, 호흡곤란이 있으면 외과적 절제술이 필요하 다. ${ }^{12)}$ 방사성 요오드를 이용한 치료도 크기를 감소시키 는데 통증과 출혈이 많기 때문에 고연령층이나 수술이 어 려운 환자에게 적응이 되며 소아에게는 생식능력의 장애 를 일으키므로 금기이다. ${ }^{13)}$

\section{중심 단어 : 이소성 갑상선. 결절성 과증식증.}

\section{REFERENCES}

1) Hickman W. Congenital tumour of the base of tongue, pressing down the epiglottis on the larynx and causing death by suffocation sixteen hours after birth. Trans Pathol Soc Lond 1869;20:160-1.

2) Hazarika P, Siddiqui SA, Pujary K, Shah P, Nayak DR, Baladrishnan R. Dual ectopic thyroid: A report of two cases. J Laryngol Otol 1998; 112:393-5.

3) Morgan NJ, Emberton P, Barton RP. The importance of thyroid scanning in neck lumps a case report of ectopic tissue in the right submandibular region. J Laryngol Otol 1995; 109:674-6.

4) Leung AK, Wong AL, Robson WL. Ectopic thyroid gland simulating a thyroglossal duct cyst. Can J Surg 1995;38: 87-9.

5) Kumar R, Khullar S, Gupta R, Marwah A. Dual thyroid ectopy: Case report and review of literature. Clin nuclear medicine 2000;25:253-4.

6) Strickland AL, Macfie JA, Van Wyk JJ, French FS. Ectopic thyroid gland simulating thyroglossal duct cysts. JAMA 1969; 208:307-10.

7) Pinczower E, Crockett DM, Atkinson JB, Kun S. Preoperative thyroid scanning in presumed thyroglossal duct cysts. Arch Otolaryngol Head Neck Surg 1992;118:985-9.

8) Kim DY, Park BG, Lee TH. A case of papillary thyroid carcinoma arising in a thyroglossal duct cyst with complete ectopic thyroid gland. Korean J Otolaryngol 2003;46:702-5.

9) Livolsi VA, Rerzin KH, Savetsky L. Carcinoma arising in median ectopic thyroid (including thyroglossal duct tissue). Cancer 1974;34:1303-15.

10) Nussbaum M, Buchwald RP, Ribner A, Mori K, Litwins J. Anaplastic carcinoma arising from median ectopic thyroid. Cancer 1981;48:2724-8.

11) Misaki T, Koh T, Shimbo S, Kasagi K, Konishi J. Dual-site thyroid ectopy in a mother and son. Thyroid 1992;4:325-7.

12) Choi JH, Kim DH, Kang HJ, Lee DJ, Lee HM. Dual ectopic thyroid. Korean J Otolaryngol 2001;44:897-900.

13) Wong RJ, Cunningham MJ, Curtin HD. Cervical ectopic thyroid. Am J Otolaryngol 1998;19:397-400. 